\title{
CONSTITUTIONAL ASPECTS OF THE COVENANT
}

\author{
JACOB D. HYMAN*
}

It has long been a commonplace that Americans, when confronted with proposals for solving a political, social or economic problem of any magnitude, tend to become obsessed with the question of constitutionality. Not infrequently the issue is exhaustively debated and resolved without explicit discussion of anything except the constitutional question, although the decisive considerations are political, social or economic. Something of the sort appears to have been happening in discussions about the proposed International Covenant on Human Rights. Since March of 1948 , there has been an article or comment about it in almost every issue of the Journal of the American Bar Association. ${ }^{1}$ Two themes have been continuously stressed: the Covenant involves serious problems which must be carefully studied; and the problems are permeated with grave constitutional and legal issues.

The appropriateness of the first theme cannot be doubted. Adoption of the Covenant would have serious implications. It would signalize an attempt, on a wholly unprecedented scale, to give positive content to an international law of man. New foci of international relations would be established; new forces would be loosed in the international field. These facts should certainly be known and understood. But there is no basis for an implication that some small, international group is attempting, by dazzling speed, to slip something past an unsuspecting American public. Quite to the contrary, the Covenant is the culmination of extensive, quite public, activity. ${ }^{2}$

The justification for prolonged insistence on the second theme is far less apparent. If the Covenant presents serious constitutional questions, it ought to be possible, after a while, to identify them, consider them, and reach a conclusion. Vague references in the course of political arguments to constitutional questions can only serve to confuse discussion of the difficult problems which do have to be faced. It seems appropriate, then, that this article should be devoted to an attempt to identify

* A.B. I931, Harvard College; LL.B. I934, Harvard Law School. Professor of Law, University of Buffalo School of Law.

${ }^{2} 34$ A.B.A.J. 200, 214, 277, 30r, 349, 388, 475, 480, 586, 654, 698, 881, 910, 984, II 22 (I948); 35 A.B.A.J. 32, 40, I28, 195, 20I, 203, 205, 217, 222, 283, 288, 406, $55 \mathrm{I}$ (1949).

2 The following list is not exhaustive: Declaration of the Rights of Man, Adopted by the Institute of International Law, 24 AM. J. INT'L L. 560 (I930); Card J. Friedrich, The New Belief IN the Coxmon Man (1942); Postulates and Principles for the International Law of the Future, Principle 2 and Comment, International Conciliation, April, I944, p. 292; Hersh Lauterpacht, AN Internationat Bril of the Rights of Man (I945); Philup C. Jessup, A Modern Law of Nations (r948); American Law Institute, Statement of Essential Human Rights, with explanatory and historical articles, 243 THE ANNALs (January, 1946). 
the constitutional questions raised by the Covenant and, within the space available, to explore the answers. ${ }^{2}$

\section{The Scope of the Covenant}

As of the summer of I949, there is no possibility of ascertaining precisely what the Covenant will contain when it is approved by the General Assembly and submitted to the member states for ratification. An original draft of the Covenant, by the Commission on Human Rights, ${ }^{3}$ was substantially re-worked by the Drafting Committee on an International Bill of Human Rights ${ }^{4}$ in the light of recommendations of the various states, and was revised again by the Commission at its Fifth Session, concluded on June 20, I949. Agreement was reached as to the substance and form of some articles to be included. On others, final action was postponed pending further study and the receipt of further information. Even as to those items on which agreement was reached, there remains the possibility of changes by the Commission itself in the light of the comments of interested states, or by the Economic and Social Council and the General Assembly when the Commission's proposal is submitted to them for approval. Apart from questions of detail, two broad issues were left unresolved by the Commission: first, whether the Covenant should remain limited to basic individual rights, or whether it should be broadened to include social and; economic rights; second, whether provisions for implementation should be included in the present Covenant or reserved for a later one and, in either event, what methods of implementation should be adopted. ${ }^{5}$

Even in the absence of a final text, however, the lines of development have been clearly enough delineated to permit identification of the issues which will be important. Thus far, there is definite agreement as to the inclusion in the Covenant of at least the basic individual rights and as to the form in which many of those should be stated. The economic and social rights, the immediate inclusion of which is still in doubt, are presumably the same in substance as the economic and social rights defined in the Universal Declaration of Human Rights, approved by the General Assembly of the United Nations on December 10, 1948. And as to the problem of implementation, there is available at least an indication of the possible approaches. $^{6}$

2a Enward S. Cormin, The Constitution and World Organization (1944) is a masterly statement of the broad thesis that the Constitution is not incompatible with full participation by the United States in new forms of world organization.

${ }^{3}$ Document E/600; E/CN.4/AC.I/I9; 3 May 1948, reprinted, 34 A.B.A.J. 202 (1948).

-Annex B., Document E/CN.4/95; Annex B, Document E/800. This draft and the draft identificd in the preceding note are reprinted with extracts from other relevant documents in a pamphlet, Docuaments for Study in the 1949 Series of Regional Group Conferences of the American Bar AssociaTION (February, 1949).

The work of the Commission at its Fifth Session is summarized by Dr. Charles Malik of Lebanon, the Commission's Rapporteur, 7 U. N. Burl. 2 (July I, 1949). For the textual decisions of the Commission, see $i d$. at 7 .

${ }^{\circ}$ Malik, stlpra note 5, at 5-6; Briggs, Implementation of the Proposed International Covenant on HItman Rights, 42 AM. J. INT'L L. 389 ( 9948 ). 
For the purpose of seeking out constitutional issues, then, the situation may be described in the following way. The United States will be asked to give its adherence to a treaty or covenant which will provide that: no one shall be deprived of his life, save in the execution of the judgment of a court (Art. 5); no one shall be subjected to torture or to cruel, inhuman or degrading punishment (Arts. $6 \& 7$ ); no one shall be held in servitude or at compulsory labor, except in stated cases, like military service (Art. 8); no one shall be subjected to arbitrary arrest or detention, and a remedy in the nature of habeas corpus shall be available to determine the lawfulness of detention (Art. 9); no one shall be imprisoned because of inability to fulfill a contractual obligation (Art. Io); subject to general laws in the interest of security, everyone has the right to freedom of movement (Art. II); aliens lawfully admitted to a state shall not be expelled except in accordance with procedure prescribed by law (Art. r2); everyone, in the determination of his civil rights or obligations, is entitled to a fair hearing before an independent and impartial tribunal, and, in the determination of any criminal charge against him, is also entitled to a public trial, a presumption of innocence, legal assistance, and an opportunity to cross-examine and to obtain witnesses (Art. 13 ); no one shall be held guilty on account of acts not unlawful when done (Art. I4); no one shall be denied freedom of thought and religion (Art. I6), freedom of speech (Art. I7), freedom of assembly (Art. I8), and freedom of association (Art. 19); and everyone shall be accorded the rights defined in the Covenant without discrimination on account of race, color, sex, etc., and entitled to equal protection against any incitement to such discrimination (Art. 20). Each state adhering to the Covenant will undertake to provide appropriate laws for the enforcement of the enumerated rights, including remedies against those who act in an official capacity (Art. 2).

In addition, the United States may be asked to undertake similarly to protect the following so-called economic and social rights now defined in the Declaration: the right to social security, "in accordance with the organization and resources of each state" (Art. 22); the right to work, to free choice of employment, to just remuneration insuring an existence worthy of human dignity, and the right to join unions (Art. 23); the right to an adequate standard of living, and to security in the event of unemployment, sickness, and old age (Art. 25); the right to education (Art. 26); the right to marry and found a family (Art. r6); and the right to own property and not to be arbitrarily deprived of it (Art. I7). Also subject to eventual inclusion would probably be the right to take part in the government of one's country, directly or through freely chosen representatives, under a system of general elections by universal and equal suffrage (Art. 2I).

These obligations, once assumed, would be enforceable at the very least by protests of other signatory states to appropriate organs of the United Nations. Almost certainly, in this connection, advisory opinions could be sought from the Court of International Justice, or a special Court on Human Rights to be constituted. Per- 
haps also individuals, groups, and organizations would be authorized to submit complaints for investigation, and possibly provision would be made for the submission of complaints directly to an international court. The suggestions to this effect do not make it clear whether the court would have jurisdiction to impose criminal sanctions on officials or private citizens charged with violation of the protected rights, or merely jurisdiction to consider violations by the state and award some form of reparation. ${ }^{7}$

Considering broadly this attempt to achieve the general goals of the Covenant, the fundamental constitutional questions include the following: May the United States contract with other nations that it will protect certain rights of its people and allow some international agency to investigate its performance? Is there anything required by these undertakings which the government of the United States could not, with due regard for constitutional limitations, now do? If so, would the act of adherence to such an international covenant affect its power? Would a possible enlargement of national power by virtue of the covenant significantly dislocate the present distribution of powers in our federal system? Is there any constitutional obstacle to our investing other states or an international body with a legal right to inquire into, and perhaps impose sanctions because of, the manner in which our citizens are treated by our officials and by other citizens? It must be emphasized that this inquiry is directed to the existence of power, not the wisdom of its exercise. And since our national government is one of enumerated powers, the point of departure for the inquiry should be the Constitution itself.

II

The Power to Make and Implement Treaties

\section{A. Constitutional Provisions}

Evidently, the treaty power was very much in the minds of the draftsmen of the Constitution. While "All legislative Powers herein granted shall be vested in a Congress of the United States" (Art. I, Sec. I), the Congress as such has no concern with the making of treaties. The nearest powers given directly to Congress are those "To regulate Commerce with foreign Nations ..." and "To define and punish Piracies and Felonies committed on the high Seas, and Offenses against the Law of Nations." However, the Congress is authorized "To make all Laws which shall be necessary and proper" not only "for carrying into Execution the foregoing Powers" but also, be it noted, "all other Powers vested by this Constitution in the Government of the United States, or in any Department or Officer thereof" (Art. I, Sec. 8).

If Congress was not to have the power to make treaties, certainly the States were not. The first of the miscellaneous inhibitions placed upon the States by Section xo of Article I is: "No State shall enter into any Treaty, Alliance, or Confederation." This is reinforced two paragraphs later: "No State shall, without the Consent of Congress, ... . enter into any Agreement or Compact with another State, or with a

\footnotetext{
${ }^{7} I d$. at note 27 .
} 
foreign Power ...." Withheld from Congress and withdrawn from the States, the treaty-making power was vested in the executive branch of the Government. Section 2 of Article II states that the President "shall have Power, by and with the Advice and Consent of the Senate, to make Treaties, providing two thirds of the Senators present concur."

The special status of treaties is recognized in the provision of Section 2 of Article III, that the "judicial Power shall extend to all Cases, in Law and Equity, arising under this Constitution, the Laws of the United States, and Treaties made, or which shall be made, under their Authority." Finally, the Supremacy clause, Article VI, gives to treaties the same superior force that the Constitution itself and laws passed pursuant to it are given: "This Constitution, and the Laws of the United States which shall be made in Pursuance thereof; and all Treaties made, or which shall be made, under the Authority of the United States, shall be the supreme Law of the Land; and the Judges in every State shall be bound thereby, any thing in the Constitution or Laws of any State to the Contrary notwithstanding."

With the concurrence of the Senate, then, the President is given power, power subject to no expressed limitation, to make treaties; and Congress is authorized to make laws necessary and proper to effectuate the treaties. These rather plain provisions seem to go far toward answering the questions stated above. In particular, they suggest that laws may validly be enacted to effectuate a treaty which, in the absence of the treaty, would have no constitutional basis.

\section{B. Missouri v. Holland and the Reserved Powers of the States as a Limitation on the Treaty Power}

If we turn to pertinent decisions of the Supreme Court, we find rather precise confirmation of the conclusions suggested by the plain words of the Constitution. Missouri v. Holland $d^{8}$ involved the validity of an act of Congress ${ }^{8}$ setting a closed season for the taking of migratory birds. The lower federal courts had held a similar statute unconstitutional, not long before, ${ }^{10}$ on the ground that Congress lacked the power to control such matters. The Government had sought constitutional footing in the commerce clause, and in the power given to Congress by Section 3 of Article IV to regulate respecting "the Territory or other Property belonging to the United States." These bases were deemed inądequate in the light of a Supreme Court holding that the States had large power, as trustees for their citizens, over wild game within their borders. ${ }^{11}$ While the issue was being brought to the Supreme Court, a treaty was negotiated with Great Britain which provided that there should be closed seasons on migratory birds and that "the season for hunting shall be further restricted to such period not exceeding three and one half months as the

252 U. S. 416 (1920).

- Migratory Bird Treaty Act of July 3, 1918, 40 STAT. 755 (Ig18), as amended, 49 STAT. 1556 (1936), I6 U. S. C. $\$ 703$ (1946).

${ }^{10}$ United States v. Shauver, 2I4 Fed. 154 (E. D. Ark. 19r4); United States v. McCullagh, 22I Fed. 288 (D. Kan. 1915).

${ }^{11}$ Geer v. Connecticut, I6I U. S. 519 (1896). 
High Contracting Powers may severally deem appropriate and define by law or regulation." The statute enacted by the United States forbade any taking of birds except as allowed by regulations of the Secretary of Agriculture. His regulations specified an open season considerably shorter than that established by the laws of Missouri. Missouri sought to enjoin federal officials from interfering with hunting by Missouri citizens during Missouri's open season. The Supreme Court affirmed the district court's dismissal of the bill. No determined effort was made to vindicate the federal legislation on any ground other than its appropriateness for implementing the treaty. In a characteristically terse and sweeping opinion, Justice Holmes, for all but two of his brethren, observed: "No doubt the great body of private relations usually fall within the control of the State, but a treaty may override its power."12

This decision was not reached without awareness of its profound implications for the relations between the National Government and the States. Indeed, Missouri's argument was based almost entirely on the proposition that to sustain the Migratory Bird Act would be to deprive the states of power over purely internal affairs, power which was reserved to them by the clear implication of the Constitution as a whole, by the crucial fact that the National Government was one of delegated powers, and explicitly by the provision of the Tenth Amendment that: "The powers not delegated to the United States by the Constitution, nor prohibited by it to the States, are reserved to the States respectively, or to the people." The Court met this argument squarely and rejected it.

To answer this question it is not enough to refer to the Tenth Amendment, reserving the powers not delegated to the United States, because by Article II, \$2, the power to make treaties is delegated expressly, and by Article VI treaties made under the authority of the United States, along with the Constitution and laws of the United States made in pursuance thereof, are declared the supreme law of the land. If the treaty is valid there can be no dispute about the validity of the statute under Article I, $\$ 8$, as a necessary and proper means to execute the powers of the Government. ${ }^{13}$

Having rejected the explicit argument from the Tenth Amendment, the Court considered the further argument "that a treaty cannot be valid if it infringes the Constitution, that there are limits, therefore, to the treaty-making power, and that one such limit is that what an act of Congress could not do unaided, in derogation of the powers reserved to the States, a treaty cannot do."14 As stated in other words: "The only question is whether it [the treaty] is forbidden by some invisible radiation from the general terms of the Tenth Amendment." ${ }^{\text {15 }}$ The answer was still no.

The decision does not hold that there is no limit to the treaty power. On the contrary, the opinion undertook to pass on the validity of the treaty: it was observed that "The treaty in question does not contravene any prohibitory words to be found

\footnotetext{
12252 U. S. at 434 .

${ }^{13} \mathrm{Id}$. at 432.

${ }^{14}$ Ibid.

${ }^{15}$ Id. at $433-434$.
} 
in the Constitution."16 And it was emphasized that the occasion was a proper one for the exercise of the treaty power: "Here a national interest of very nearly the first magnitude is involved. It can be protected only by national action in concert with that of another power."17

The nature of the true limitations upon the treaty power and their relevance to the Covenant will be discussed later. To be emphasized now is the weight and clarity of the holding in Missouri v. Holland that neither a treaty, nor national legislation implementing it, is invalid because it regulates private relations which are normally within the power of the States and which, but for the treaty, would be beyond the control of the National Government. As has been stated, this decision was reached in the face of the strongest protestations that it would subvert the federal basis of our government. There is no doubt that the rule pronounced by the decision could have that effect. Indeed, the treaty power has on occasion been referred to as, in effect, a way of amending the Constitution. This overstates the result in one very important particular. It is well settled that in so far as a treaty is effective as a law of the land under the Supremacy Clause, it may be repealed by a subsequent act of Congress. ${ }^{18}$ Important as this qualification is, it does not alter the fact that under Missouri $v$. Holland, the exercise of the treaty power may result in the National Government's taking over the regulation of matters which it could not otherwise touch.

Missouri $v$. Holland did not altogether escape criticism. ${ }^{19}$ And, in view of the implications of its holding, it may not be inappropriate to inquire whether the decision is at variance with prior or subsequent doctrine of the Supreme Court. There are dicta to be found in opinions of the Supreme Court around the middle of the nineteenth century indicating that some justices espoused the doctrine urged by the State of Missouri. ${ }^{20}$ But those dicta have been shown to be at variance with the consistent holdings of the Supreme Court whenever the invalidity or ineffectiveness of a treaty was asserted on the ground of interference with the powers of the States. The whole problem was exhaustively and acutely examined by Edward S. Corwin in a book published in I913: National Supremacy, Treaty Power vs. State Power. ${ }^{21}$ That examination establishes as conclusively as reasoned argument can that the prevailing doctrine was the same as the doctrine announced in Missouri $v$. Holland. Viewed against its background, that decision is obviously no aberration, to be dismissed lightly or confined narrowly to controversies involving migratory wild life.

\footnotetext{
${ }^{10} I d$. at 433 .

${ }^{17}$ Id. at 435 .

${ }^{18}$ Head Money Cases, II2 U. S. 580, 598-599 (1884); The Chinese Exclusion Case, I30 U. S. $58 \mathrm{I}$ ( 889 ).

${ }^{10}$ See Black, Missouri v. Holland-A Iudicial Milepost on the Road to Absolutism, 25 ILL. L. Rev. 9 II (I93I).

${ }^{20}$ See particularly Daniel, J., in The License Cases, 5 How. 504, 613 (U. S. 1847); Taney, C. J., dissenting in The Passenger Cases, 7 How. $283,465-466$ (U. S. I 849 ).

${ }^{21}$ The principal authorities are collected and briefly reviewed in Boyd, The Expanding Treaty Power, 6 N. C. L. REv. 428 (I928).
} 
Developments since that decision reinforce its important holding. In the first place, we have had in United States v. Darby an explicit re-affirmation of Justice Holmes's statement about the Tenth Amendment: "The amendment states but a truism that all is retained which has not been surrendered."22 Secondly, in several other areas there has been a substantial collapse of the notion that the necessity for preserving the powers of the States by implication restricts the National Government in the exercise of its specifically granted powers. A notable example is in the field of intergovernmental immunities, where Graves v. New York ex rel. O'Keefe ${ }^{23}$ overruled the venerable Collector v. Day, ${ }^{24}$ which had rested on a rather broad implication of state-generated limitations on federal taxing power to protect the salaries of state officers from federal taxation. It can hardly be doubted that the implied limitation on the federal taxation power which a scant majority of the Supreme Court found, in United States v. Butler, ${ }^{25}$ to prevent regulation of "local" matters "reserved" to the States, would no longer be recognized. ${ }^{26}$ And in the area of national control of interstate commerce, a group of cases has abandoned the doctrine that the mere existence of state governments limits the scope of the national power to regulate commerce. ${ }^{27}$

Finally, in the area of external relations itself, several decisions have notably lengthened the reach of the national power. The culminating decision was United States $v$. Pink, ${ }^{28}$ upsetting the New York court's order for the distribution of the New York assets of a Russian insurance company, on the basis of a transfer of Soviet claims to the United States under the Litvinov Assignment, which was a letter to the President of the United States from the People's Commissar for Foreign Affairs, confirming an understanding arrived at between them. The majority opinion rested upon the following vigorous statement: ${ }^{29}$

We repeat that there are limitations on the sovereignty of the States . . Power over external affairs is not shared by the States; it is vested in the national government exclusively. It need not be so exercised as to conform to state laws or state policies, whether they be expressed in constitutions, statutes, or judicial decrees.

The case has been criticized primarily because of its apparent extension of the power to make executive agreements which, unlike treaties, do not require the approval of the Senate. ${ }^{30}$ That controversy is not pertinent here. What is presently significant

22312 U. S. roo, 124 (194I).

24 xr Wall. $\operatorname{Ir}_{3}$ (U. S. 1870 ).

${ }^{23} 306$ U. S. 466 (1939).

25297 U. S. I (1936).

${ }^{20}$ See Helvering v. Davis, 301 U. S. 619 (1937); Mulford v. Smith 307 U. S. 38 (1939); Wickard v. Filburn, 3 I7 U. S. III (I942).

${ }^{27}$ NLRB v. Jones \& Laughlin Steel Corp., 30r U. S. I (1937); United States v. Darby, 3 I2 U. S. roo (1941); Wickard v. Filburn, 317 U. S. III (1942); Stern, The Commerce Clante and the National Economy, 1933-1946, 59 Harv. L. Rev. 645, 883, 946 (1946). Mr. Justice Roberts, since his retircment, has proposed constitutional amendments to limit the federal taxing and spending and commerce powers. See To Amend the Constitution: Curbs on Dangerous Centralization Are Proposed, 34 A.B.A.J. 649,651 (1948).

${ }^{28} 315$ U. S. 203 (1942). ${ }^{20}$ Id. at 233.

${ }^{30}$ See Note, 48 Col. L. Rev. 890 (1948), citations at notes 2, 3; Borchard, The Proposed Constitutional Amendment on Treaty-Making, 39 AM. J. INT'2 L. 537, 538 (1945). 
is that the dissent of the Chief Justice, joined by Justice Roberts, questioned only the adequacy of the evidence to show that the agreement in question had been intended to override state policy like that asserted by New York; there was no suggestion of a lack of federal power to override that policy. The dissent declares that the mere act of recognition of a foreign government without more cannot "be said to imply a deprivation of the constitutional rights of states of the Union and of individuals arising out of their laws and policy, which are binding on the Federal Government except as the act of recognition is accompanied by some affirmative exercise of federal power which purports to set them aside."31

In the light of these developments, there seems to be no reason to doubt that Missouri $v$. Holland is conclusive authority for the proposition that the adherence of the United States to an International Covenant on Human Rights would not be held unconstitutional for the reason that it might increase national power over relations otherwise within the exclusive control of the States.

\section{Other Limitations on the Treaty Power}

This conclusion, if sound, disposes of only one aspect of the inquiry. It will be recalled that Justice Holmes suggested two other aspects in stating that the treaty in question did "not contravene any prohibitory words to be found in the constitution" and that there was involved a national interest which could "be protected only by national action in concert with that of another power." These two propositions suggest the two limitations on the treaty power which have been accepted by the courts and commentators with impressive consistency. Thus, for example, the leading case of Geofroy v. Riggs contains a much-quoted statement by Mr. Justice Field :32

The treaty power, as expressed in the Constitution, is in terms unlimited except by those restraints which are found in that instrument against the action of the government or of its departments, and those arising from the nature of the government itself and of that of the States. It would not be contended that it extends so far as to authorize what the Constitution forbids, or a change in the character of the government or in that of one of the States, or a cession of any portion of the territory of the latter, without its consent ... But with these exceptions, it is not perceived that there is any limit to the questions which can be adjusted touching any matter which is properly the subject of negotiation with a foreign country.

This last qualification was stated earlier in the opinion," as follows: "That the treaty power of the United States extends to all proper subjects of negotiation between our government and the governments of other nations is clear."

${ }^{31} 315$ U. S. at 253.

${ }^{32}{ }_{133}$ U. S. 258,267 ( 1890 ). The last clause of the first sentence quoted could, with some strain, be construed as suggesting a limitation like the one rejected in Missouri $v$. Holland. But it seems, considering the next sentence, that the limitation "arising from the nature of the government ... of the States" which Mr. Justice Field was referring to was one which would bar "a change in the character of the government . . o of one of the states ...., not one which merely shifted power over certain relations from the state to the Federal Government.

${ }^{83}$ I33 U. S. at 266. 


\section{Does the Covenant Require What the Constitution Forbids?}

Would adherence to the proposed Covenant be prevented by either of the foregoing limitations? Certainly in so far as the substantive obligations of the proposed Covenant in its present form are concerned, there can be no question about contravening "any prohibitory words to be found in the Constitution." Under this test, we may assume, a treaty could not validly provide that negroes should not be allowed to vote, or that all arms factories should be nationalized without compensation, or that on the happening of specified contingencies the United States should be in a state of war. ${ }^{34}$ But far from conflicting with any constitutional ban, each of the provisions now in the draft Covenant echoes a declaration of right found in our own Bill of Rights or in the Thirteenth, Fourteenth or Fifteenth Amendments: the right not to be arbitrarily deprived of one's life; the right to be free from arbitrary detention; the right to be free from involuntary servitude; the right to the equal protection of the laws; the right of defendants in criminal proceedings to elementary safeguards of fairness. In this connection, it is interesting that the representative of Yugoslavia, voting against the earlier draft of the Covenant because of its limited scope, charged that it had been prepared "mainly with a view to bringing it into line with the laws at present in force in two countries: the United Kingdom and the United States." ${ }^{35}$

Nor does it appear that the addition to the Covenant of social and economic rights like those specified in the Declaration would create a conflict with any constitutional limitation. The United States has already adopted, with the sanction of the Supreme Court, measures to implement substantially all of the economic rights under consideration. We have a nationwide system of old-age insurance, ${ }^{36}$ a cooperative federal-state system of unemployment insurance, ${ }^{37}$ a far-reaching federal system of minimum wage and maximum hour standards, ${ }^{38}$ supplemented by state systems primarily for the protection of women and minors in industries not covered by the federal system. ${ }^{39}$ Even the "right to work" has already been recognized as a national responsibility in the Employment Act of $1946^{40}$ and in the furnishing of employment

${ }^{34}$ As to the application of the Fifth Amendment, see Note, 48 CoL. L. REv. 890, 897-899 (1948); as to the efficacy of an advance declaration of war, see I W. W. Willoughis, The Constitutionar. Law of THE UNITED States 526 (2d ed. 1929 ). This may be a rather theoretical problem in view of the power of the President to place the nation in a situation in which war might be forced upon it. Sec Edward S. Cormin, The President, Office and Powers 246-250 (i940).

${ }^{35}$ Report of the Working Party on an International Convention on Human Rights, E/CN. 4/56, II Dec. 1947, quoted in Briggs, supra note 6, at 396.

${ }_{36}$ Helvering v. Davis, 3or U. S. 619 (1937), upholding the Social Security Act of 1935, 49 Srar. 620,42 U. S. C. c. 7, Subchapters II and VIII, $\$ \$ 401$ and 100I (1946).

${ }_{32}$ Carmichael v. Southern Coal Co., $30 \mathrm{r}$ U. S. 495 (1937) and Steward Machine Co. v. Davis, 301 U. S. 548 ( 1937 ), upholding Subchapters III and IX, \$\$50I and IIor.

${ }^{38}$ United States v. Darby, 312 U. S. 100 (194I), upholding the Fair Labor Standards Act of 1938 , 52 Stat. I060, 29 U. S. C. \$201 (1946).

${ }^{39}$ West Coast Hotel Co. v. Parrish, 300 U. S. 379 (1937); see the reference to the state statutes at 390-39r.

\$0 60 STAT. 23, 15 U. S. C. \$I02I (1946). The "declaration of policy" rcads: "The Congress declares that it is the continuing policy and responsibility of the Federal Government to use all practicable means consistent with its needs and obligations and other essential considerations of national policy, 
on federally supported projects during the depression of the Thirties. ${ }^{41}$ Apparently the only specific right of this character recognized in the Declaration but not yet implemented by federal action is the right to medical care. Despite the vehement opposition to the proposed national health insurance program, there has been no serious suggestion that it would not be constitutional. Characterization of the economic rights set out in the Declaration as the foundation for an international "New Deal," requiring a "planned economy" and promoting "state socialism, if not communism, throughout the world"42 would seem to be political hyperbole. If such characterizations were intended to suggest a constitutional argument, it should be noted that Article I7 of the Declaration recognizes the right of everyone "to own property" and not to "be arbitrarily deprived of his property," closing the door to confiscation. As far as socialism is concerned, it would be difficult to demonstrate that the Constitution proscribes the public ownership of the means of production. ${ }^{42^{a}}$ And, while a theory has been advanced that economic planning by the state inevitably causes the loss of all personal freedom, ${ }^{43}$ the theory has not yet had the verification necessary to allow it to stand as a constitutional argument against planning. Unless that theory is relied upon, there is no discernible basis, in law or in fact, for the charge that the Covenant is at variance with our fundamental concept of individual rights and freedom. ${ }^{44}$

With one notable exception, the suggestions thus far made for enforcing the Covenant do not appear to present any constitutional questions requiring discussion. The Commission on Human Rights has agreed in principle only that

with the assistance and cooperation of industry, agriculture, labor, and State and local governments, to coordinate and utilize all plans, functions, and resources for the purpose of creating and maintaining, in a manner calculated to foster and promote free competitive enterprise and the general welfare, conditions under which there will be afforded useful employment opportunities, including self-employment, for those able, willing, and seeking to work, and to promote maximum employment, production, and purchasing power."

"Sce the discussion of the scope of unemployment and the remedies adopted in the Steward case, 301 U. S. at 586-587.

"Holman, An "International Bill of Rights": Proposals Have Dangerous Implications for United States, 34 A.B.A.J. 984 , 1080 (1948). In the same address Mr. Holman emphasized the failure of the Covenant "to give first importance to a right like that . . . of conducting business under a free enterprise system." Id. at 985 . Yet it is perfectly obvious that no provision proposed for the Covenant prohibits the continuation of a system of free enterprise. Of course recognition of some of the economic and social rights may require restrictions on the conduct of free enterprise similar to those now existing in the United States. Possibly the opposition of the American Bar Association stems from a fear that adherence to the Covenant may interfere with efforts to repeal the laws imposing those restrictions, just as there is an avowed fear that adherence might frustrate efforts to "achieve a change or modification in the recent adverse decision by the Supreme Court" holding that the enforcement by state equity courts of racial restrictive covenants violated the Fourteenth Amendment (Shelley v. Kraemer, 334 U. S. I (1948)). Id. at 1079.

42n See Black, Socialism and the Constitution, 28 ILL. L. REv. 3 I3 (1933).

${ }^{4}$ The leading tract is Friederich A. von HAYeK, The Road to Serfdom (1944). Among the contrary-minded, see Herman Finer, The Rond to Reaction (I945), Alvin H. Hansen, Economic Policy and Full Employment, particularly App. A. (I947), and John M. Clark, Alternatives to Serfodom (I948).

4" This charge is made by Holman, supra note 42, at 985. At other times, Mr. Holman has suggested that the Covenant would destroy "our constitutional and legal system" (35 A.B.J.A. 201 (1949)), and that it is in conflict "with the basic principles of our form of goverament." Id. at 362 . 
signatory states should have the right to enter complaints initiating proceedings against violations of human rights. ${ }^{45}$ The further proposal that complaints may be lodged by individuals, groups, and organizations has divided the Commission. The United States opposed the use of this device in the early stages of the Covenant, although it has been most persuasively argued that to restrict enforcement to com. plaints by states would trivialize the Covenant, making it just another weapon of power politics, and would dangerously frustrate the aspirations it represents. ${ }^{40}$ All nations, however, except the Soviet Union and those identified with it, favor some form of international machinery for implementing the obligations of the Covenant. At the least, this would probably involve discussion and recommendations by the General Assembly and other organs of the United Nations of asserted violations. A further possibility is the establishment of a special organ of the United Nations having the jurisdiction and duty to supervise and take steps toward the enforcement of human rights of its own motion, either before the International Court of Justice or a newly created International Court on Human Rights. ${ }^{\mathbf{4 7}}$

A novel constitutional problem would arise if the International Court were given jurisdiction to impose sanctions directly on officials and citizens of signatory states. The pattern for this type of enforcement is to be found in the convention on Genocide, now before the United States Senate for ratification, ${ }^{48}$ which includes a clause (Article V) providing that individuals who violate the terms of the Covenant shall be punished by an international tribunal, if jurisdiction has been conferred upon it. The General Assembly, when it approved the Convention, adopted a resolution requesting the International Law Commission to study the possibility of creating such an international judicial organ. Does the treaty-making power authorize the President, with the concurrence of the Senate, to make a citizen amenable to trial and punishment by a foreign tribunal for acts committed within the jurisdiction of the United States? Ultimately, the question becomes one of the power of the United States courts to prevent or review such a proceeding, as by ordering the dismissal from custody of one held for extradition. In various aspects, the war power has been exercised to subject citizens as well as aliens within the power of the United States to tribunals the proceedings of which were not reviewable by the regular courts of the United States, including the Supreme Court. Examples are the trial by military tribunals of members of the armed forces, of prisoners of war or others charged with violating the laws of war, and of civilians in areas in which martial law prevails. ${ }^{49}$ Typically in those cases investigation by the United States courts is limited

${ }^{4}$ Malik, supra note 5 , at 2,5 .

${ }^{16}$ Ibid. Simsarian, Third Session of the UN Commission on Human Rights, 42 Axs. J. INT'L L. 879, 882-883 (1948).

17 Briggs, supra note 6, at 389-395.

${ }^{48}$ Letter of Transmittal and Report of the Secretary of State to the President, 21 DEP'T STATE BuLL. 844 (1949).

${ }^{10}$ See Duncan v. Kahanamoku, 327 U. S. 304, 313-3I4 (1946), and cases cited; Charles Fairman, The Law of Martial Rule, cc. III, IX (1930); Fairman, The Law of Martial Rule and the National Emergency, 55 HARv. L. REv. I253 (1942), The Supreme Court on Military Jurisdiction, 59 Harv. L. REv. 833 ( 1946 ). 
to the question whether the detention complained of is within the authority of those detaining the petitioner, and does not extend to the mode of conducting the proceedings. ${ }^{50}$

It may well be that a similar rule should mark the limit of intervention in the activity of a duly constituted international tribunal. Authority for this suggestion may be found in the recent decision of the Supreme Court in Hirota v. General of the Army Douglas MacArthur. ${ }^{51}$ Japanese officials and military commanders sought leave to file petitions for writs of habeas corpus challenging the propriety of their detention pursuant to orders of the International Military Tribunal of the East, which had found them guilty of war crimes against humanity and had condemned them to death. The refusal of jurisdiction was rested, by a majority of the Court, on the ground that since the tribunal which sentenced the petitioners was not a tribunal of the United States, but had been set up by General MacArthur as the agent of the Allied Powers, the courts of the United States were without authority to review the judgments or sentences. Justice Douglas concurred on the ground that the Tokyo Tribunal was not a judicial tribunal, but solely a political instrument, created by the authority of the President of the United States as Commander-inChief; and the courts, of course, lack power to review political questions. ${ }^{52}$ Justice Douglas thought that inquiry should not stop with the question whether the tribunal was international; but that the Court should also consider whether there was authority to try the defendants for the precise crimes with which they were charged. ${ }^{53}$ But the conclusion of Justice Douglas, like that of the Court, indicates that the power of the courts of the United States would be severely limited with respect to the functioning of an international tribunal established to enforce fundamental human rights. On this assumption, apparently, it has been suggested that adherence by the United States to a covenant on implementation establishing such a tribunal might result in exposing citizens of the United States to trial and punishment through proceedings lacking the procedural safeguards we regard as essential to fairness. (3. $^{\mathrm{a}}$ But the possibility seems insubstantial in view of the fact that the

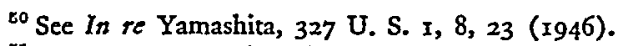

${ }^{\text {E1 }} 69$ Sup. Ct. 197 (1949).

${ }^{82} 69$ Sup. Ct. at $1238,1243,1246$.

${ }^{8}$ Id. at $1241-1242$.

4sa Rix, Humant Rights and International Law: Effect of the Covenant, 35 A.B.A.J. 55I, 620 (I949).

There is, of course, a possibility that the Supreme Court might regard as invalid a treaty, and an extradition statute implementing it, which subjected citizens to criminal trials without safeguards. The rationale might be that such a treaty transgressed the constitutional limitations on the conduct of criminal proceedings, although this would be stretching the amendments beyond their apparent purpose of assuring the prescribed safeguards in proceedings conducted by the Federal Government or its agencies. Even on such a theory the requirements of grand and petit jury would not apply, since a proceeding before an international court is pretty plainly not one with which the jury was traditionally associated. CF. Ex parte Quirin, 3I7 U. S. I, 38-44 (I942). Probably the only safeguards that would be deemed applicable would be the generalized ones of the due process clause of the Fifth Amendment. Cf. Murphy, J., dissentiing, in In Re Yamashita, 327 U. S. I, 26-27 (1946). And, as observed in the text, the proposed covenant would certainly provide that much protection.

Judge Orie L. Phillips, discussing the Genocide Convention, suggests that if the United States ratifies that Convention it should do so with an explicit reservation that it will not in the future consent to con- 
Covenant on Human Rights itself sets forth the essential safeguards, including the right to a fair and public hearing before an independent and impartial tribunal, to prompt notice of the nature of the accusation, to the assistance of counsel, to the examination of adverse witnesses, to the compulsory attendance of witnesses, and to a presumption of innocence. ${ }^{54}$

\section{Does the Covenant cover a Proper Subject of Negotiation between our Govern- ment and the Government of other Nations?}

If neither the reserved powers of the States nor any specific prohibition in the Constitution bars adherence by the United States to an International Covenant on Human Rights, the remaining constitutional question is whether such an act would be a proper exercise of the treaty-making power. As we have seen, Geofroy v. Riggs suggests that the treaty power "extends to all proper subjects of negotiation between our government and the governments of other nations"; that there is no limit "to the questions which can be adjusted touching any matter which is properly the subject of negotiation with a foreign country." While Justice Holmes did not attempt, in Missouri v. Holland, to formulate the test, he did point out that the treaty there in question involved an important national interest which could "be protected only by national action in concert with that of another power." In Hauenstein v. Lynham, ${ }^{55}$ the Court quoted approvingly Calhoun's statement that, with specified exceptions, "all questions which may arise between us and other powers, be the subject-matter what it may, fall within the treaty-making power and may be adjusted by it." The net effect of the judicial pronouncements on the subject has been summarized by Professor Charles Cheney Hyde in the following question: "Is there the requisite association with the International relations of the

ferring upon an international tribunal jurisdiction to try violations by individuals. The Genocide Convention: Its Effect on Our Legal System, 35 A.B.A.J. 623, 624-5 (1949). To adopt this suggestion would seem gratuitously to discourage efforts to make some progress toward a more effective international law.

54 "Perhaps it is necessary at the outset to purge our common law minds of current misconceptions about the French criminal law in general. So far from proceeding on a 'presumption of guilt, the presumption of innocence was a formal part of the French constitution, and was enforced at least as consistently as it is in England or America. Again, ex post facto laws'were prohibited, as well as double jeopardy. One might add, that differently from the common law, the accused always had the not unsubstantial advantage of being the last to address the jury." Radin, Martial Law and the State of Siege, 30 CALIF. L. REv. 634, 636 (1942). This all too necessary admonition applics as well to the other nations of western Europe. The absorbing negotiations leading to the procedural provisions for the International Military Tribunal have recently been published: INTERNATTONAL CoNFERENCE on MiLItary Truals, Dep't State Pub. 3080 (1949).

Perhaps approval of the Covenant by the General Assembly, with the present clause requiring the assignment of counsel, will be a sufficient indication of the growth of prevailing conceptions of fairness to allow the Supreme Court to discard, for the future, the fiction, particularly painful under our adversary system, that a defendant in a felony case is likely to have a fair trial without the assistance of counsel. Cf. Bute v. Illinois, 333 U. S. $640,663-665$ (1948), where Mr. Justice Burton, for the Court, seems to suggest that some precipitating event may allow the Court to hold that counsel has become necessary, without thereby causing a nationwide jail delivery.

${ }^{55}$ I00 U. S. 483,490 ( 1879 ). 
United States? ${ }^{356}$ Or, as Professor Willoughby has put it: "In short, the treatymaking power is to be exercised with constitutional bona fides."

Looking broadly at these statements, one might perhaps dismiss any question about the legitimacy of the Covenant with the simple observation that our adherence would obviously be a bona fide act most important to our international relations and not a colorable device for increasing the reach of federal power. The Covenant is part of the cooperative effort of more than a score of nations, large and small, to establish an international order that will eliminate or at least minimize the threat of future wars. The effort was stimulated by the all too persuasive evidence that an atomic war of the future would create havoc many times greater than the scarcely credible destruction visited upon the earth and its peoples by World War II. At the very outset, the cooperating nations expressed their conviction that one of the conditions necessary for peaceful and friendly relations among nations is universal respect for and observance of human rights and fundamental freedoms. In ratifying the Charter of the United Nations, the United States at the very least pledged itself to assist in the promotion of those goals. ${ }^{58}$ This should be enough to put beyond question the propriety of adopting the Covenant under the treaty power.

There have been suggestions, however, that the subjects of the rights which would be created by the Covenant and the nature of the obligations imposed make it something beyond the scope of the treaty power. Perhaps the objection is implicit in Professor Willoughby's statement that "the treaty-making power may not be used to secure regulation or control of a matter not properly and fairly a matter of international concern." 59 More explicitly, perhaps, it appears in a statement of the late Chief Justice Hughes at a discussion before the American Society of International Law:

But if we attempted to use the treaty-making power to deal with matters which did not pertain to our external relations but to control matters which normally and appropriately were within the local jurisdiction of the States, then I again say there might be ground for implying a limitation on the treaty-making power that it is intended for the purpose of having treaties made relating to foreign affairs and not to make laws for the people of the United States in their internal concerns through the exercise of the asserted treatymaking power. ${ }^{60}$

If the reference to intention here does not make the test equivalent to Professor Willoughby's bona fides test, the idea seems to be that the relations between the

${ }^{50}$ Proc. AMr. Soc'y INr'L L. 52 (1937).

${ }^{27} \mathrm{x}$ WILLOUGHBY, op. cit. supra note 34 , at 569 .

${ }^{68}$ U. N. Charter, Preamble; Art. 55(c); Art. 62, \$2; Art. 68. It is assumed here that the acceptance of the Charter merely obligated the United States to cooperate in further steps to achieve basic human rights and did not forthwith obligate the United States to secure those rights to its citizens. This problem is discussed brietly infra p. 467.

${ }^{50} \mathrm{Y}$ WILLOUGHBY, op. cit. supra note 34 , at 569 .

${ }^{\circ 0}$ Proc. Am. Soc'y INT'I L. (I929), quoted in Rix, Human Rights and International Law: Effect of the Covenant, 35 A.B.A.J. 55I, 554-6r8 (1949). 
United States and their own people have nothing to do with foreign affairs and therefore are not a proper subject of the treaty-making power. A more recent expression of a similar concept starts with the premise that international relations involve states; whereas

A bill of rights ... has nothing to do directly with the relations between governments; it exists primarily to define the relations between a government or state and the individual citizens thereof: basically it relates to internal affairs and not to international matters. ${ }^{01}$

This distinction, it is argued, is recognized and adopted in Article II, sub-paragraph 7 of the U. N. Charter which states that "Nothing contained in the present Charter shall authorize the United Nations to intervene in matters which are essentially within the domestic jurisdiction of any state . ...62 The argument is developed by reference to statements of proponents of the Covenant that it is revolutionary in character in that it acknowledges the individual human being as a person in international law, that it gives him rights directly, whereas heretofore the traditional doctrine has been that international law is only a law between states, that it takes account of injuries to individuals only insofar as the injury to them may be said to be an injury to their state. ${ }^{.3}$

In substance, the foregoing argument means that the United States is constitutionally incapable of participating in a revolutionary step in the development of international law. It is submitted that any such contention is patently untenable. Certainly the decisions of the Supreme Court do not support it; they do not suggest that the treaty-making power is limited to those things known to international law in I789. Having recognized in so many other fields that the Constitution is a living document whose grants must be construed in the light of changing conditions and new problems, it would be strange indeed if the Court should apply a much more restrictive canon of interpretation in the favored area of foreign affairs. ${ }^{04}$

Furthermore, if the ideas implicit in the proposed Covenant are revolutionary, they are so only in terms of the scale on which they are to be applied. There has been an unmistakable trend toward the recognition of individual rights in inter-

e1 Holman, stupra note 42 , at 985 .

${ }^{62}$ Id. at 1080.

${ }^{63}$ Rix, stipra note 60, at 553, quoting from Philip C. Jessup, A Modern LAw of Nations 137 (1948); Holman, supra note 42, at 1081, quoting Humphrey, International Protection of Human Rights, 255 THE ANNals I5 (1948). Jessup's book is in large part a re-examination of the established rules of international law in the light of the assumption, which he urges as essential for the development of world order, that individuals do have rights cognizable in international law. The same position is urged by H. LAUTerpacht, AN INTERnattonal BiLl of the Rights of MAN (I948). The conventional rule, and some exceptions, are explained in I Chardes C. Hyde, International Law Chiefly as INTerPRETED AND APplied By THE UNTTED STATES, \$§IIA, riB, riC (2d ed. r947).

64 The words of the late Chief Justice Hughes in Home Building \& Loan Ass'n v. Blaisdell, 290 U. S. 398, 442-443 (r934) are pertinent: "It is no answer to say that this public need was not apprehended a century ago, or to insist that what the provision of the Constitution meant to the vision of that day it must mean to the vision of our time. If by the statement that what the Constitution meant at the time of its adoption it means today, it is intended to say that the great clauses of the Constitution must be confined to the interpretation which the framers, with the conditions and outlook of their time, would have placed upon them, the statement carries its own refutation." 
national law. Aliens have been protected in the exercise of rights conferred upon them by treaty, and citizens have been protected while abroad. International law has accommodated the anomaly by the fiction that in each case the state was injured. ${ }^{65}$ The fiction was badly strained by the minorities provisions in the Paris Peace Treaties following World War I. These plainly imposed upon states an obligation to assure specified kinds of protection to certain of their citizens. ${ }^{66}$ As World War II drew to a close, there seemed to be a growing feeling throughout the world that the attainment of a decent international order was, in part at least, dependent upon securing a worldwide recognition of basic human rights. It was reflected in the declaration of the Four Freedoms and in the Atlantic Charter. ${ }^{67}$ It began to take shape at the Mexico City Inter-American Conference on Problems of War and Peace which, in I945, proclaimed the support of the American Republics of a system of international protection of the essential rights of man. ${ }^{68}$ Popular articulation of that feeling is said to have been responsible for the vastly greater emphasis on individual human rights in the U. N. Charter, than in the Dumbarton Oaks proposals. ${ }^{69}$ As has already been indicated, the Charter is pervaded with the theme of individual human rights. Because of this emphasis, it has been argued that the Charter alone establishes as a postulate of international law the human rights of individuals, and imposes upon the signatory states an obligation to respect those rights. ${ }^{70}$ In general, representatives of the United States have disclaimed any such effect for the Charter itself. ${ }^{71}$ But even assuming that the Charter does not have decisive effect, it quite evidently represents at least a tremendous stride toward a new orientation of the place of the individual in international law. Professor Manley O. Hudson, while deploring an extreme interpretation of the Charter, recently declared that the Charter makes an advance in substantive international law:

It supplies clear recognition of limits on the old concept of domestic jurisdiction. Certain subjects covered by the Charter were not previously covered by international legislation, but one can no longer contend that they fall within the range of merely domestic jurisdiction. The principal of those subjects is that of human rights. ${ }^{72}$

of Jessup, op. cit supra, note 63 , at 9 and c. V.

${ }^{\circ}$ See Kunz, The Future of the International Law for the Protection of Minorities, 39 AM. J. INT'L L. 89 (I945); Note, 47 Col. L. Rev. 268 (I947); Jacob Robinson et al, Were the Minorities Treaties A Faruure? (I943); Lauterpacht, op. cit. supra note 63, c. XIV; Azcárate, Protection of Minorities and Human Rights, 243 THE Annaxs 124 (1946).

${ }^{\circ 7}$ Annual Message of President Roosevelt, January 6, I94I; Atlantic Charter, August 14, I94I.

${ }^{o s}$ Ninth International Conference of American States, Bogota, Colombia, 1948, Report of the Delegation of the United States, Dep't State Publication 3263, 79-82; Fenwick, Pan-American Action for Protection of Human Rights, 243 ThE Annals 139 (1946).

${ }^{\circ O}$ Humphrey, supra note 63 , at 15 .

${ }^{70} \mathrm{Sec}$ the quotations from the report to the Human Rights Committee of the International Law Association at Brussels, 1948 , on the legal effects of the Charter in relation to the domestic jurisdiction clause, Rix, stpra note 60, at 6r8-6rg. Cf. Sayre, Shelley $v$. Kraemer and United Nations Law, 34 Iows L. REv. I (x948); Humphrey, supra note 63 , at 17 .

${ }^{71}$ See statement by Eleanor Roosevelt, Dec. 9, x948, I9 DeP'T State BuLl. $751-752$ (1948).

${ }^{72}$ Proc. Ax. Soc'y INT'L L. II (1948). Cf. Kunz, The United Nations Declaration of Human Rights, 43 AM. J. INT'L L. 3r6, 318 (r949). 
Mention should also be made of the fact that in the recent treaties of peace, Bulgaria and Hungary assumed specific obligations under international law to secure human rights and fundamental freedoms to all persons under their jurisdiction. It is on the basis of those obligations that the United States has challenged before the United Nations Bulgarian and Hungarian attacks on church leaders. ${ }^{73}$

In the face of these developments, there surely can be no serious claim that the recognition and protection of basic human freedoms is not a "proper subject of negotiation between our government and the governments of other nations."

\section{The Consequences of the Supremacy Clause}

Generally, international treaties merely have the effect of imposing upon each of the signatories an obligation to the others, under international law, to do what it promised. If a treaty calls for a change in legal relations within a contracting state, the state must take appropriate legislative or executive action to bring about the change in domestic law. But from the very beginning, the Supreme Court has held that treaties duly adopted by the United States must be given the same effect by the courts as federal laws. ${ }^{74}$ If the rights or obligations of parties before the court are affected by the terms of a treaty, the court must decide the case accordingly, even if there has been no legislation putting the treaty into effect. For example, stipulations in a treaty fixing the amount and the method of determining the liability of aircraft carriers to their passengers on international flights, control litigation between carriers and passengers in the state and federal courts. ${ }^{75}$ Whether or not a treaty has this effect depends on how the courts interpret its obligations. If the treaty in plain terms simply obligates the United States to pass legislation affecting legal relations, the treaty will be given no effect in the absence of legislation. ${ }^{70}$ Also, treaty obligations may be of such a character that they would not be likely to become involved in any judicial proceedings in the absence of legislation. This would be true of a treaty obligation to extradite a fugitive from the justice of another nation.

In the absence of a clear stipulation to the contrary, it is clear enough, then, that the obligations of the Covenant would immediately become relevant in litigation before the courts. Detailed consideration of how far they would be self-executing would be futile without knowledge of what their precise form will be at the time of ratification. In general, however, it seems clear that the so-called economic rights would not be self-executing. The civil rights, for the most part, could be judicially enforced in the same way that the provisions of the Fourteenth and Fifteenth

${ }^{73}$ See statement of B. V. Cohen before the Ad Hoc Political Committee on April I8, 1949, 20 Dep'T State Buzr. 556-560 (May I, I949); 35 A.B.A.J. 514 (I949).

${ }^{7}$ Ware v. Hylton, 3 Dall. x99, 244, 277 (U. S. 1796); Foster v. Neilson, 2 Pet. 253 (U. S. 1829); Aguilar v. Standard Oil Co., 318 U. S. 724,738 (I943), concurring opinion of the Chicf Justice.

${ }^{76}$ Wyman v. Pan-American Airways, Inc., 181 Misc. 963,43 N. Y. S. 2d 420, affd, 267 App. Div. 947, 48 N. Y. S. 2d 459 (1943); Indemnity Ins. Co. of N. America v. Pan American Airways, Inc., 58 F. Supp. 338 (S. D. N. Y. 1944).

${ }^{78}$ Ex parte Dove, 49 F. 2d 816 (D. Minn. 1925). A ruling in Foster v. Neilson, 2 Pet. 253 (U. S. I829) that a treaty provision was not self-executing was overruled in United States v. Percheman, 7 Pct. 5I (U. S. I833). 
Amendments are now enforced; by direct review or habeas corpus proceedings to annul judicial or administrative action which conflicts with them. They would not seem likely to raise any new problems, because they merely cover in part ground already covered more fully by those amendments.

Is there any basis for alarm in the fact that by virtue of the Supremacy Clause some provisions of the Covenant will be self-executing in the United States and not in other nations? It has been suggested that the consequences will be so horrendous that the word "revolutionary" fails to describe them. ${ }^{77}$ The reasons for this extraordinary concern are hard to see. Clearly, the important problem of federal-state relations is not affected. For, if the provisions are not self-executing, it is clear, under Missouri v. Holland, that Congress will have whatever power is needed to implement them. There are, to be sure, some practical differences depending on whether provisions are self-executing or not. For one thing, a treaty requires the approval of two-thirds of the Senate, whereas implementing legislation would require the approval of a majority of both the Senate and the House of Representatives. Again, other nations may ratify and then fail to implement, while the United States, merely by ratifying, will forthwith translate some of its obligations into domestic law. But the risk that other nations will flagrantly disregard their obligations while we honor ours is no less great whether the treaty becomes effective domestically through implementing legislation or through its own force. In either event, the United States has available the remedies of international law, or of self-help in the form of the passage of statutes which nullify the domestic effect of the treaty. ${ }^{78}$ Finally, the courts of the United States, in applying self-executing provisions, might follow the interpretations of some international agency authorized to consider violations of the treaty, even if in construing implementing legislation they might have arrived at a different interpretation because of special problems in the United States. ${ }^{\text {70 }}$ But such a conflict is most unlikely in connection with any provisions of the Covenant thus far proposed which would be self-executing. Certainly neither this remote possibility nor the other indicated consequences of self-executing provisions seem to be of such serious nature as to influence our decision to participate in the Covenant.

If, for reasons that have not yet been made apparent, it should be deemed important to prevent any provisions of the Covenant from being self-executing, it

${ }^{77} \mathrm{Rix}$, supra note 60 , at 554 . See also Holman, supra note 42 , at 985 ; Holman, Comments, 35 A.B.A.J. 288,360 (1949).

${ }^{78}$ As has been pointed out above, the power of Congress to overcome by legislation the domestic effect of treaties is well established. The Chinese Exclusion Case, 130 U. S. 58x (1889). Other methods are probably available to disencumber ourselves of the domestic effect of treaty obligations. See EDWARD S. Corwin, The President, Office and Powers 243 (1940).

${ }^{70}$ The dogma is that the courts, in the interpretation of treaties, should follow the lead of the political departments of the nation. See Marshall, C. J., in Foster v. Neilson, 2 Pet. 253, 307 (U. S. I829). A close student of the problem has concluded that, despite the dogma, there is a discernible impulse on the part of American courts to follow considerations reflecting the demands of the international legal order as they conceive it. See Louis L. Jaffe, Judicial Aspects of Foreign Relations 4-7, 75-78 (I933). One would expect, therefore, that the pronouncements of a duly established international tribunal would carry great weight. 
should be noted that nothing in the drafts to date would appear to have that effect. The provisional draft of the clause specifying the obligations of the contracting states (Article 2) reads:

Each State party hereto undertakes to ensure to all individuals within its jurisdiction the rights defined in this Covenant. Where not already provided by legislative or other measures, each State undertakes, in accordance with its constitutional processes and in accordance with this Covenant, to adopt within a reasonable time such legislative or other measures to give effect to the rights defined in this Covenant.

Section 2 calls for the assurance of an effective remedy before national tribunals even when violations are committed by persons acting in an official capacity. The Supremacy Clause would seem to be an existing "measure" for the enforcement of the rights set forth in the Covenant. Hence it would be perverse to read this Article 2 as preventing the Covenant from being self-executing.

As presented by the drafting committee, the Covenant also contained a FederalState clause reading as follows:

In the case of a Federal State, the following provisions shall apply:

(a) With respect to any articles of this Covenant which the Federal Government regards as wholly or in part appropriate for federal action, the obligations of the Federal Government shall, to this extent, be the same as those of parties which are not Federal States: (b) In respect of articles which the Federal Government regards as appropriate under its constitutional system, in whole or in part, for action by the constituent states, provinces, or cantons, the Federal Government shall bring such provisions, with favourable recommendation to the notice of the appropriate authorities of the states, provinces or cantons at the earliest possible moment.

It would seem that this clause was designed to make possible the adherence of federal states the central government of which lacked power to enact the legislation to implement all the obligations of the Covenant. ${ }^{80}$ As has been shown above, there is little reason to doubt that the United States Government has whatever power is necessary to implement its treaty obligations; or, in other words, that federal action by the United States is appropriate with respect to all articles of the Covenant. For the Federal Government of the United States, after ratifying the Covenant without reservation, to show by some formal act that it regarded implementation by itself as inappropriate would seem to be an outright breach of faith. It would be a deliberate repudiation of existing power to effectuate its obligations. But even if a disclaimer of national power were duly recorded, ${ }^{81}$ it would appear to affect only

\footnotetext{
${ }^{80}$ The same provision, with additional procedures for implementing obligations not within the sphere of the Federal Government appears in the 1946 constitution of the International Labor Organization, which was approved by the United States in 1948 (62 STAT. I151). The problems are somewhat different in that the ILO constitution establishes a framework for handling treaties to be proposed by the ILO in the future. See the explanation by Sohn, The Development of International Law, 35 A.B.A.J. 217 (1949).

${ }^{81}$ There might be a nice question as to what authority would make the disclaimcr: The President? the President and the Senate? the Congress? Under United States v. Curtiss-Wright Export Corp., 299 U. S. 304 (1936), and United States v. Pink, 315 U. S. 203 (I942), the power would probably lie with the President.
} 
the distribution of power between the States and the Federal Government to pass legislation implementing those provisions of the Covenant which were not selfexecuting. It is most doubtful that the disclaimer would be construed as annulling the provisions of the Covenant which being self-executing had already become effective. These considerations indicate that the Federal-State clause alone would not prevent the Covenant from being self-executing in the United States. ${ }^{\mathbf{2}}$

From the analysis thus far, a few general conclusions may be drawn with considerable assurance. First and foremost, there is nothing in the Constitution to prevent the United States from effectively ratifying, or from exercising the national legislative power to implement, an International Covenant on Human Rights which conforms substantially to the proposals already made. Second, unless specific provisions are included to limit drastically the character of the obligations assumed by the United States, many provisions of the Covenant will become operative in the United States without the benefit of legislation. Third, no substantial disadvantage can be anticipated because some provisions will be self-executing. These conclusions suggest one more fundamental inquiry; even if adherence to the Covenant is constitutionally permissible, will it alter drastically the distribution of power between the States and the National Government?

\section{III}

\section{Effect of Ratification of the Covenant on Federal-State}

\section{Relations in the United States}

Reluctance to accept the authority of the decision in Missouri $v$. Holland stems in part from a fear that the treaty power may be made the basis for the complete destruction of the existing balance between federal and state powers. ${ }^{83}$ Conceivably the future development of international law may raise that problem in different and acute forms. But the immediate question is the validity of the assumption that, because of Missouri v. Holland, the effect of the proposed Covenant on Human Rights would be revolutionary.

In the unlikely event that the Covenant as first approved by the U. N. will contain the so-called economic rights, they will create no special problem of federal-state relations. As has been explained above, those rights are such as can be protected only by the kind of national action which has already been determined to lie within the competence of the Federal Government. ${ }^{84}$

In the area of civil rights, however, to which the first Covenant will probably be

${ }^{82}$ Cf. Ransom, International Legislation and the American System, 22 Tulane L. Rev. 547, 554 $(\mathrm{r} 948)$.

${ }^{83}$ See Rix, supra note 60 , at 618 .

${ }^{84}$ See notes 36-4I supra, and accompanying text. In so far as the right to work is concerned, the Havana Charter for an International Trade Organization will, if ratified, commit the United States internationally to "take action designed to achieve and maintain full and productive employment and large and steadily growing demand within its own territory through measures appropriate to its political, economic and social institutions." Quoted in Bronz, The International Trade Organization Charter, 62 HARv. L. REv. Iogo, IIIg (I949). 
limited, the impact is directly upon immediate and intense conflicts over the proper roles of the State and Federal Governments. Here, presumably, if anywhere, the adoption of the Covenant would have a revolutionary effect. It is necessary, therefore, to examine the extent to which the Federal Government now has power to protect civil rights and then to consider how far that power would be broadened by the adoption of the Covenant.

It is schoolboy learning that when our Constitution was ordained, the Founding Fathers, although reasonably satisfied with the power structure in their state governments, were concerned over the possibility of tyrannical use of the new sovereign power they were creating. In response to widespread demand, a group of amendments was adopted, hard on the heels of the Constitution itself, enumerating specific limitations on the powers of the Federal Government. Barron v. Baltimore ${ }^{85}$ shocked no expectations in holding that the Bill of Rights did not operate as a limitation on the States. The lines were clear: the power of the Federal Government was duly shackled by the Federal Constitution; except for a few items designed for the protection of creditors, the Constitution left to the citizens through the ballot and the state constitutions the problem of protecting their liberties from state and local invasion. ${ }^{86}$

So things remained until the nation undertook to secure the fruits of a long, bitter, and costly civil war. The Thirteenth Amendment put federal power behind rights other than those of creditors. The institutions of slavery and involuntary servitude were no longer to "exist within the United States" and Congress was authorized "to enforce this article by appropriate legislation." Whatever the defects of their program and however mixed their motives may have been, those who formulated a program of reconstruction were wise enough to know that man is not free merely because he is relieved of physically coerced bondage to another. They accordingly enacted a series of laws, the Civil Rights Acts, designed to interpose a federal barrier against measures which had been taken in some states to deny full equality to the freedmen. ${ }^{87}$ Doubts were voiced that the Thirteenth Amendment furnished adequate authority for some of these laws. To remove the doubts, the Fourteenth and then the Fifteenth Amendments were enacted. ${ }^{88}$ Drafted in the face of hostile state legislation, they not too surprisingly departed somewhat from the form of the Thirteenth Amendment: where the latter had proscribed the fact of involuntary servitude, the former enjoin that "No State" should "make or enforce any law which

${ }^{85}{ }_{7}$ Pet. 243 (U. S. 1833 ).

${ }^{80}$ Familiarity has blunted awareness of the magnitude of the invasion of state freedom by the obligation of contract clause (U. S. ConsT. Art. I, \$10, par. I) and the bankruptcy clause (id. Art. I, $\$ 8$, par. 4).

${ }^{87}$ The Civil Rights Acts are summarized in Biddle, Civil Rights and the Federal Law, in Sareguarding Civil Liberty Today I20 (I945); Robert K. Carr, Federal Protection of Civil Rigitrs 35-55 (1947).

${ }_{88}$ The authoritative history is Horace E. Flack, The Adoption of the Fourteenth Amendenent (1908). A brief summary may be found in the dissenting opinion of Justice Black in Adamson $v$. California, 332 U. S. 46, 68-123 (r947). 
shall abridge the privileges and immunities of citizens of the United States"; nor shall "any State deprive any person of life, liberty, or property, without due process of law"; and the right to vote shall not be denied or abridged "by any State" on account of race, color, or previous servitude. Both amendments, like the Thirteenth, authorized Congress to enact appropriate legislation for enforcement. Here, seemingly, was a revolution in federal-state relations. Apparently the power of the Federal Government was being invoked to protect the whole range of civil rights, to assure freedom in fact.

But constitutions mean what the courts say, and the Supreme Court most emphatically said that these amendments did not cause a revolution. In the Slaughter House Cases, ${ }^{89}$ the Court reduced the privileges and immunities clause to a tautology $y^{90}$ by excluding from its scope any rights which might be said to belong to free men generally: these, said the Court, were privileges and immunities of state citizenship, not of national citizenship, and therefore not protected by the Amendment. This and other decisions were seemingly effective in suppressing the revolution. ${ }^{91}$ The result has been simply and accurately put by a commentator who heartily approved:

The primary purpose of the adoption of the Fourteenth Amendment was to elevate the negro to a place of equality with the white people and to assure his newly given rights. In its attempts to carry out this ideal, Congress was effectually restrained by the Supreme Court.92

Although the Court in accomplishing this feat purported to rely on the intentions that produced the Amendments, ${ }^{93}$ there is a later judicial admission that those intentions were perhaps not entirely respected. In 1908, in Twining $v$. New Jersey, Justice Moody said that the Slaughter House Cases "undoubtedly gave much less effect to the Fourteenth Amendment than some of the public men active in framing it intended, and disappointed many others."

Apparently stifled at the outset, the revolutionary force began to move in a new direction. In the last part of the nineteenth and the early part of the twentieth century there were increasing appeals by business interests to the due process clause of the Fourteenth Amendment for protection against troublesome state regulations. ${ }^{95}$ The Court heeded the appeals. Federal power was increasingly invoked to protect citizens against the actions of their own states. But when the waters began to rise, they could not be confined to the channel of business interests; inevitably they flowed

${ }^{80} 16$ Wall. 36 (U. S. 1873 ).

${ }^{0}$ Edvard S. Corwin, The Constrtution and What It Means Today 187 (9th ed. 1947).

${ }^{01}$ The story is well told in Watt and Orlikoff, The Coming Vindication of Mr. Justice Harlan, 44 ILl. L. REv. 13 (1949).

${ }^{02}$ Charles W. Collins, The Fourteenth Amendment and the States $16 \mathrm{r}$ (1912), quoted in Watt and Orlikoff, supra note $9 \mathrm{I}$, at $\mathrm{Ig}$.

${ }^{03}$ I6 Wall. $36,67-68$ (U. S. 1873 ).

${ }^{04} 211$ U. S. 78, 96 (1908).

${ }^{\circ}$ See Benjamin R. Twiss, Lawyers and the Constrtumons: How Laissez Faire Came to the SUPREMIE COURT (1942). 
into the area of civil rights. ${ }^{96}$ Since 1926 the due process clause of the Fourteenth Amendment has been rapidly expanded to protect civil rights against attacks not launched by the Federal Government. Freedom of the press, speech, religion, assembly, the right to a fair trial by an impartial tribunal, the assistance of counsel if necessary for a fair trial, the right not to be convicted on the basis of coerced testimony or of testimony known by the prosecution to be perjured ${ }^{07}$ - with the recognition that the due process clause includes these rights and freedoms, the arm of the Federal Government reaches far into the relations between States and their citizens.

But that is not the end of the story. An effective limit appeared to exist, for a time, in the fact that the prohibitions of the Fourteenth and Fifteenth Amendments ran only against action by the States-the Amendments did not guarantee the rights in a general way. At one time there was a tendency to hold that "state action" included only state laws or those acts of state officials which had been authorized by state laws.98 More recently state action has been found whenever an official of the state, acting in an official capacity, deprives a person of a constitutionally protected right, although the act constituting the deprivation be done without the sanction, or in violation, of state law.9

The latest cases have departed farther from the original, formalistic conception of the kind of state action prohibited by the Fourteenth and Fifteenth Amendments. Most striking has been the series of election cases. Smith v. Allwright ${ }^{100}$ overruled Grovey $v$. Townsend ${ }^{101}$ to hold that where the primary elections were regulated by statutes of Texas, the exclusion of negroes from membership in the Democratic Party not by statute, but merely by action of the party's own state convention, amounted to state action denying the right to vote on account of race, contrary to the Fifteenth Amendment. South Carolina's response was to repeal all provisions in her Constitution and statutes relating to primaries. The operation of the primaries was taken over by the Democratic Party. Taking cognizance of the decisive role of the primaries and of the fact that the general elections as managed by the State rested upon the functioning of the primaries, the District Court in South Carolina held the exclusion of negroes from the primary to be forbidden state action. The Supreme Court declined to review the affirmance of this decision by the Court of Appeals. ${ }^{102}$

os "The water had been rising for a hundred and thirty odd years, until in 1925 it lapped quictly over the sill." Charles P. Curtis, JR., Llons Under the Throne 267 (1947).

${ }^{{ }^{27}}$ Grosjean v. American Press Co., 297 U. S. 233 (1936); Thomas v. Collins, 323 U. S. 516 (1945); West Virginia v. Barnette, 319 U. S. 624 (1943); De Jonge v. Oregon, 299 U. S. 353 (1937); Moore v. Dempsey, 26 I U. S. 86 (1923); Powell v. Alabama, 287 U. S. 45 (1932); Haley v. Ohio, 332 U. S. 596 (1948); Mooney v. Holohan, 294 U. S. 103 (1935).

${ }^{8 s}$ Barney v. City of New York, I 93 U. S. 430 (1904).

${ }^{\circ 0}$ Home Tel. \& Tel. Co. v. Los Angeles, 227 U. S. 278 (1913); Screws v. United States, 325 U. S. 9 I (1945).

${ }^{100} 32 x$ U. S. 649 (1944).

101294 U. S. 699 (1935).

${ }^{202}$ Elmore v. Rice, 72 F. Supp. 516 (E.D.S.C.), $a f f d, 165$ F. $2 d{ }^{8} 87$ (C.C.A. 4 th 1947), cert. denied, 333 U. S. 875 (1948), Note, 96 U. of PA. L. Rev. 402 (1948), 48 Cor. L. Rev. 124I (1948). 
It is against the background of this development, all too summarily sketched here, that the current foci of dispute must be examined. They are to be found in the civil rights legislation which has been requested by the President in the last few sessions of Congress: federal protection against lynching; a federal prohibition on discrimination in employment; and federal banning of the poll tax. The various bills proposed to reduce lynchings include three features: federal prosecution of state officials whose connivance or negligence makes them possible; the assessment of penalties against the communities through the default or connivance of which they occur; and federal prosecution of private citizens who participate in the lynchings. ${ }^{103}$ The present concept of state action under the Fourteenth Amendment would seem to assure the validity of the first two types of action against lynching. ${ }^{101}$ Even isolated instances of culpable inaction by the state or local officials would seem to fall within the concept. Similar situations are regarded in international law as providing a basis for a claim against the state. ${ }^{105}$ But in any event, a systematic pattern of state inaction, just as surely as a statute excepting from the penal code's definition of murder the killing of negroes charged with crime, would unquestionably justify the invocation of federal protective legislation. The only doubtful question is whether federal statutes could constitutionally be invoked against the actual perpetrators of the lynching. The relation to the election cases is more than tenuous. If our courts deemed it expedient to look squarely and hard at the social role played by lynchings in maintaining an inferior status for the negroes, they could see that the lynch mob, in an area in which violence or the threats of it are systematically condoned, is in fact performing a state function.

This last step may be farther than the courts would be willing to go now. If so, perhaps this is one point at which adherence to the Covenant would authorize the passage of federal legislation which would not otherwise be valid. The creation of the power does not, of course, make its exercise inevitable. Federal sanction for non-official lynchers might not be an indispensable step toward the fulfillment of a treaty obligation to protect individuals against improper deprivation of life. Reasonable sanctions to compel state enforcement of existing laws might well be regarded as sufficient. But here, probably, is some expansion of federal power.

The second major issue is the prohibition of discrimination in employment. A basis for comprehensive federal legislation against such discrimination has been thought by the President's Committee on Civil Rights to lie in the cumulative economic effects of suppressing minority groups. ${ }^{106}$ Perhaps this chain of economic consequences is too attenuated to support federal action. ${ }^{107}$ There can be little doubt,

${ }^{103}$ A typical bill is analyzed in Comment, 47 MrCH. L. REv. 369 (1949).

${ }^{104}$ See Note, 57 YALE L. J. 855 (1948); Comment, 47 Mich. L. Rev. 369 (1949).

${ }^{100} 2$ HYDE, op. cit. supra, note $63, \$ \$ 289$, 290. See also In Re Yamashita, 327 U. S. T, I6 (1946).

100 To Secure These Rights, Report of the President's Committee on Civil Rights, $141-x 46$, 167 (1947).

${ }_{107}$ There is some doubt as to how attenuated an economic effect on interstate commerce may be before the Court will hold it inadequate to support federal legislation. With Justice Cardozo's opinion 
however, that as a practical matter a prohibition against the shipment in interstate commerce of goods produced in an establishment in which discriminatory employment practices are applied would effectively settle this problem. And there can be as little doubt that such a measure would be held constitutional. Indeed, violently as the proposal has been fought, opponents seldom raise the constitutional issue. ${ }^{108}$ It may be that the federal power to effectuate national policy by the use of an embargo on interstate shipments is less sweeping than suggested by Justice Holmes in his famous dissent in the first Child Labor Case, ${ }^{100}$ despite the recognition given that dissent in the opinion of the Court in United States v. Darby. ${ }^{110}$ But if the embargo power is limited by the necessity for some relationship between the commerce banned and the evil aimed at, the relationship appears to be present where discriminatory employment practices are the target. ${ }^{111}$ As to this issue, therefore, the ratification of the Covenant would not appear to affect materially the question of federal power.

The third issue now in controversy concerns the poll tax. Since the Covenant as now proposed does not include the right to universal participation in free elections, this issue will probably not be affected in the near future. But even if such a right would later be included, in form similar to Article 2I of the Declaration, no substantial enlargement of federal legislative power would follow. The consensus is that there is already adequate basis for eliminating the poll tax in federal elections. ${ }^{122}$ As a practical matter, that would probably eliminate the issue as far as local elections were concerned.

One important phase of civil rights has not yet been referred to: the right of access, without discrimination, to places of public accommodation. In the Civil

in Schechter v. United States, 295 U. S. 495, 55I, 554 (1935), compare Wickard v. Filburn, 317 U. S. III (I942) and Mandeville Island Farms v. American Crystal Sugar Co., 334 U. S. 219 (1948). Sec also United States v. Sullivan, 332 U. S. 689 (1948), Note, 43 ILL. L. REv. 389 (r948).

${ }^{108}$ Hunt, The Proposed Fair Employment Practices Act, Facts and Fallacies, 32 VA. L. Rev, x, 3-4 (I945).

${ }_{100}$ Hammer v. Dagenhart, 247 U. S. $25 \mathrm{I}, 277$ (I9I8).

110 312 U. S. I00 (I94I).

${ }^{11}$ Cf. Powell, The Child Labor Law, the Tenth Amendment, and the Commerce Clause, 3 So. L. Q. I75 (I918), 3 Selected Essays on Constitutional Law 314, 335 (I938): "No one can quarrel with the Supreme Court for insisting that there must be a limit to the conditions which Congress may attach to prohibitions of interstate transportation. . . . So Congress could not prescribe that a man should not ship goods across state lines in case he violated his marriage vows. There would be no nexus between the infidelity and the transportation. But there is a nexus between making goods and shipping them. Evil in the making grows by the transportation it feeds on. Transportation increases child labor. It aids in an evil which is a menace to the attainment of national objects. Congress cannot obliterate the evil. But it should be allowed to lessen it by denying it aid from the enjoyment of the highways under national control. If ever it should go further and seek to apply its commerce power to evils in no way dependent upon the commerce subject to its control, then the Supreme Court may with wisdom declare that it has failed to make a legitimate connection between its prohibition of transportation and the circumstances in which the prohibition is conditioned." But see Green, Some Herefical Remarks on the Federal Power Over Commerce, 31 MinN. L. Rev. I21 (1947); Collins, Constitutional Aspects of the Truman Program, 44 ILL. L. REv. I (1949).

112 The arguments and authorities are considered in Kallenbach, Constitutional Aspects of Fedcral Anti-Poll Tax Legislation, 45 Mrcr. L. REv. 7I7 (1947); Christensen, The Constitutionality of National Anti-Poll Tax Bills, 33 MrNn. L. REv. 217 (1949). But see Morse, Unconstitutionality of the Proposed Federal Abolition of the Poll Tax, 52 Dick. L. Rev. 163 (1948). 
Rights Case $^{113}$ a statute prohibiting discrimination by the owners of restaurants, inns, and public transportation facilities was stricken down as beyond the power conferred upon the Federal Government by the Fourteenth Amendment. No recent cases directly affect the authority of that decision. Yet it must be evident that its correctness is brought in question by the disintegration of the old concept of state action, at least in so far as it affects facilities which are licensed by the state or locality. ${ }^{114}$ The effect of the Covenant on this problem is not too clear. Article 20 asserts that "all are equal before the law" and that "everyone shall be accorded all the rights and freedoms defined in this Covenant without discrimination." By itself, this clause would hardly seem to furnish greater protection than is afforded by the present conception of state action. However, Article $x_{9}$ provides that "Everyone has the right to freedom of association with others." It is possible to read this as banning discriminatory denial of access to public places where people meet, although it is not clear that this was intended. The same doubts arise in connection with the impact of these clauses on the state practice of segregating races while offering ostensibly equal facilities to both groups. ${ }^{115}$ This practice is now being challenged under the equal protection clause of the United States Constitution. ${ }^{116}$ A realistic appraisal of the situation in the world today makes it seem unlikely that Articles $x 9$ and 20 will be construed as involving a frontal attack on the practice of segregation. If they should be so construed, adherence to the Covenant might substantially enlarge the scope of protection which the Federal Government may afford against racially repressive practices.

Today's conflict in the United States over civil rights is about the exercise rather than about the existence of power; it is more political than constitutional. So, too, the greatest effect of adherence to the Covenant will be political. What will be most important, if we ratify, will be the legal obligation we assume to the world to hasten our lagging steps toward the full recognition of human rights which, we so insistently proclaim, makes the democratic way of life the right way for the world.

One thing should be noted by those who believe that the mere fact that there would be some accretion of federal power should keep us from ratifying the Covenant. A good part of the world may, perhaps, decide to go ahead without us. If it does, there will one day be an international law of human rights which Congress will have full authority to enforce under its express power "To define and punish.... Offenses against the Law of Nations."117

Dr. Charles Malik, Minister of Lebanon in the United States and Rapporteur of

213 109 U. S. 3 (1883).

114 It may be necessary to distinguish between licenses generally and those which confer a franchise. See Madden v. Queens County Jockey Club, 296 N. Y. 249, 72 N. E. 2d 697 (1947). Watt and Orlikoff, supra note $9 \mathrm{r}$, at $39-40$, express the opinion that the Civil Rights Cases are likely to be overruled.

${ }^{116}$ Missouri ex rel. Gaines v. Canada, 305 U. S. 337 (1938); Sipuel v. Board of Regents, 332 U. S. 63 ז (I948).

${ }^{110}$ See Sweatt v. Painter, No. 667, October Term 1948, United States Supreme Court, continued to October Term 1949, No. 44.

${ }^{117}$ Cf. United States v. Arjona, 120 U. S. $479,487-488$ (1887). 
the Human Rights Commission, concluding his summary of work of the Commission at its recent session, said:

Either there is a common morality about man which can be codified and not only respected but also actually observed under a rule of law, or we are on the verge of chaos. ${ }^{118}$

In the same statement he posed a question:

Are those, whose culture and tradition contain at their core the truest conception of human dignity, so encumbered and distracted by the contradictions and pressures of their own civilization that they can no longer lead in the active realization, under international law, of a well-articulated, authentic conception of man?

The proposed Covenant puts this question directly before the American people. They must decide now how they want to answer it. There are risks, no doubt, in asserting leadership through participation in new institutions like the Covenant. They should be fully explored and carefully weighed. But the American people can make the decision; their Constitution does not foreclose the issue.

${ }^{118}$ Malik, supra note 5 , at 6. 